\title{
Legitimacy and Crime: Theorising the Role of the State in Cross-National Criminological Theory*
}

\author{
Amy Nivette, Ph.D. \\ Nuffield College \\ University of Oxford \\ Oxford, United Kingdom \\ Tel: +44 (0) 1865278502
}

Email: amy.nivette@sociology.ox.ac.uk

*Draft accepted for publication in Theoretical Criminology.

Biography: Amy Nivette is a Postdoctoral Prize Research Fellow at Nuffield College, University of Oxford. 


\title{
Legitimacy and Crime: Theorising the Role of the State in Cross-National Criminological Theory
}

\begin{abstract}
One of the primary components of state stability and order is that the citizens consider those in power just and legitimate. Citizens who perceive the state as legitimate are likely to hold its institutions as a valid source of morality and social control. Theoretically, legitimacy should play an important role in criminal offending across countries. This link between state power and citizens - i.e. legitimacy - has the potential to be an important social mechanism connecting state actions to individual criminal behaviours. With this in mind, this paper explores how political legitimacy might affect levels of crime and violence across countries. A lack of legitimacy may lead citizens to 1 ) reject the monopoly of physical force to employ self-help (Black, 1983) and/or 2) withdraw commitment from institutions, breaking down social control (LaFree, 1998).
\end{abstract}

Keywords: legitimacy, comparative criminology, state, multilevel theory, social control

Funding Acknowledgement: This research received no specific grant from any funding agency in the public, commercial, or not-for-profit sectors. 


\section{Introduction}

In her recent survey of cross-national research, Stamatel (2009a, p. 17) emphasised that comparative criminologists must move beyond the limited explanatory power of traditional grand theories (e.g. modernisation and conflict) to theorise about "regime types, efficacy and legitimacy of governments" and incorporate "political factors, especially the role of the state in maintaining law and order." Much crossnational criminology uses the state as an aggregation unit containing a range of characteristics such as democracy or GDP, but rarely does it give full attention to the role the state plays in forming and changing these characteristics. Theorists such as Norbert Elias (1939/2000), Max Weber (1978) and Thomas Hobbes (1651/1996) specifically attributed changes in social organisation to attributes of the state, most notably its ability to centralise and monopolise the use of force within its boundaries.

This paper argues that the state is not only a unit containing a set of aggregate characteristics, but is a functioning and often decisive actor in building and maintaining social order. As such, the concept of the state and its associated political, economic and legal institutions provide a useful analytic framework for understanding differences between and within countries in outcomes like economic prosperity, social inequalities and crime (Acemoglu, Johnson and Robinson, 2005; Bates, Block, Fayad and Hoeffler, 2012; Karstedt, 2010). In particular, the dynamic of power between the state and its citizens, as well as between political and other institutions, offers a link between broad macro-structural forces and individual or collective behaviours.

One of the primary components of state stability and order is that the citizens consider those in power just and legitimate. Citizens who perceive the state as legitimate are likely to hold its institutions as a valid source of morality and social control. This link between state power and citizens - i.e. legitimacy - has the potential to be an important social mechanism connecting state actions to criminal behaviours. With this in mind, this paper explores how the state, and specifically political legitimacy might affect levels of crime and violence across countries. Expanding upon the work of Nivette and Eisner (2013), two possibilities are proposed: a lack of legitimacy may lead citizens to 1 ) reject the monopoly of physical 
force to employ self-help (Black, 1983) and/or 2) withdraw commitment from institutions, breaking down social control (LaFree, 1998).

The following section reviews definitions and roles of the state in relation to society in order to frame the argument that the state is essential to social order. Then current cross-national theories of crime are evaluated in relation to the role of the state, and finally two pathways are presented linking the state to levels of crime via legitimacy. The present focus is on cross-national and comparative criminology because of the centrality of the state in this area of research as both a unit of analysis and as a possible risk factor. However, it is important to note that legitimacy is an inherently multilevel phenomenon (Bottoms and Tankebe, 2012), and therefore is relevant to examining variation in crime within and across countries, groups, or neighbourhoods (Kirk and Papachristos, 2011; Nivette and Eisner, 2013; Tyler, 2004).

\section{The State, Monopolisation and Compliance}

Theorists often refer to Weber's (1978) definition of a state: a centralised, administrative apparatus that holds a monopoly over the use of physical force within a given territory (see Beetham, 1991; Elias, 1939/2000; Gilley, 2009; Mann, 1986). The key ingredient here is the monopoly of violence. Elias (1939/2000, p. 268) argued that the state has a "monopoly" when the "[f]ree use of military weapons is denied the individual and reserved to a central authority of whatever kind." Individuals are only granted the use of physical force where dictated by legal and social norms (e.g. a parent may discipline his/her child, an individual may fight back if provoked) (Weber, 1978). With monopolisation, the state has authority over a range of human behaviours, ${ }^{1}$ and implicit in the concept of monopoly is the idea that this authority must be demonstrated and accepted across a large, diverse population. Thus in order to understand how the state maintains control over certain human actions (in this case violence), it is necessary to discuss how the state demonstrates its authority and ensures acceptance. Essentially, the state is capable of enforcing its authority through direct and indirect means. Direct means generally refer to formal techniques of social control operated by the criminal justice system 
and the rule of law, whereas indirect control operates through institutions by instilling a sense of willing cooperation, or "normative compliance" (Bottoms, 2002).

\section{Types of Authority and Compliance}

The institution of state control that applies the most direct form of power is the criminal justice system (Tankebe, 2008; Tyler, 2006; Tyler and Fagan, 2008). These state agents essentially operate by means of physical coercion and the threat of force, e.g. visible police patrols, arrest, imprisonment or execution. However, the most pervasive manifestation of state power is the rule of law (Bingham, 2010). In this basic sense, the rule of law is a fundamental tool of instrumental compliance. In law, the state's monopoly of force is codified for all to obey. As a result, the criminal justice system is only the visible fraction of the state's power to gain compliance. The ultimate authority is the law, or as Thomas Paine put it, "law is king" (1776, p. 44).

The use of direct power in gaining citizens' "instrumental" compliance is generally based on the idea that humans are self-interested, calculating actors (Hough, Jackson, Bradford, Myhill and Quinton, 2010). The state's display of force maintains its monopoly by threatening or physically punishing those who do not comply. By this method, the state's ability to maintain social order requires a vast number of criminal justice power-holders to increase the risk and visible threat of punishment for non-compliance. While some research suggests that direct rule is not an effective or cost-efficient method of maintaining social order (Hough et al., 2010; McCoun, 1993; Tyler, 2004), police, courts and prisons nevertheless send an important signal to citizens that the law will be enforced. In societies where the criminal justice system is corrupt, non-functioning, or ineffective, there is little certainty of punishment and hence little deterrent effect (see Apel and Nagin, 2011). Therefore direct rule has the some benefit in demonstrating the state's monopoly of force, and may in fact be effective in deterring certain crimes in certain contexts (e.g. post-conflict societies, failing or failed states).

In contrast to direct authority, indirect authority relies on a number of social institutions that instil routines and embed state-sanctioned norms and morals regarding violent behaviours (Karstedt, 2010). Through these institutional patterns, the state ensures social order not through threat, but through voluntary co- 
operation, or "normative compliance" (Bottoms, 2002). Normative compliance relies on an individual or group's positive attitudes towards state social institutions, in particular the criminal justice system and the rule of law. Focusing on the criminal justice system, Tyler (2006) argued that if citizens perceive that the law reflects their own beliefs (morality) and the police have the right to enforce these rules (legitimacy), they are more likely to willingly abide by the non-violent rules of the state.

Since normative compliance rests generally on an individual's morality and institutional legitimacy, the state has two routes by which to maintain order: influencing the individual and improving institutional legitimacy. In the former route, moralities are cultivated (i.e. either promoted or discouraged) by power-holders through institutions of socialisation (e.g. school, family, work). ${ }^{2}$ Importantly, one must not overstate the role of the state in individual or group morality. As Mann (1986) argued, there are numerous sources of power in societies that exert competing control over behaviours, beliefs and morals (i.e. economic, ideological, military).

The second route concerns the state's right to hold power that limits individual behaviours. In order to maintain a monopoly on force, the state and its delegate power-holders (i.e. police, courts, schools) must justify to citizens that its actions conform to the rules, are administered fairly and coincide with citizens' moralities (Tyler, 2006). Thomas Paine declared that "law is king", but he qualified that "lest any ill use should afterwards arise, let the crown...be demolished, and scattered among the people whose right it is" (1776, p. 44). When a state is considered legitimate - when it has the "right to rule" (Gilley, 2009) - citizens accept its monopoly and comply with the law because they supposedly share a normative understanding about appropriate social behaviours. Tyler (2006) and more recently Bottoms and Tankebe (2012) have shown that the perceived legitimacy of a state and its power-holders is one of the most important factors in securing widespread normative compliance.

Indeed, numerous scholars have argued the centrality of legitimacy in understanding how political power commands obedience (Beetham, 1991; Coicaud, 2007; Habermas, 1976; LaFree, 1998; Tyler, 2006; Weber, 1978). Legitimacy not only 
encourages citizens to co-operate with state power-holders when required (e.g. reporting a crime, obeying a police officer's request), it instils an obligation and commitment to orderly behaviours in everyday life (Karstedt, 2010; LaFree, 1998). The state's power to maintain social order arguably hinges not on its display of force, nor its manipulation of socialisation practices, but on whether its citizens consider the state's authority as just.

\section{Mechanisms of Legitimation}

Weber (1978) argued that:

Experience shows that in no instance does domination voluntarily limit itself to the appeal to material or affectual or ideal motives as a basis for its continuance. In addition every such system attempts to establish and to cultivate the belief in its legitimacy (Weber, 1978, p. 213).

Bottoms and Tankebe (2012) highlighted Weber's use of the word "cultivate" and the importance of power-holders' active pursuit of positive belief. The state must continually prove its right to regulate the use of force and in turn citizens must recognise and confer this power to the state. In this sense, legitimacy is conditional, or in Bottoms and Tankebe's (2012) words, dialogical.

This necessarily intertwines citizens and the state, forming a reciprocal relationship based on legitimacy. The result is a continual cycle of claim and response (Bottoms and Tankebe, 2012): the state makes a claim to power (i.e. the monopoly of force), citizens judge the claim based on its alignment with their own moralities and existing laws, and can either accept and comply or reject. In turn, the state may either adjust its actions to correspond with citizens' moralities or coerce obedience by increasing punitiveness (see Karstedt, 2010, p. 350). However, as previously mentioned, the display of force only increases instrumental compliance in certain circumstances (Apel and Nagin, 2011). Thus the state's more effective option for order is to engage in the dialogue and "cultivate" citizens' approval and normative compliance (i.e. increase legitimacy).

Understanding the mechanisms by which legitimacy works to maintain social order requires a closer look at this dialogue, or how the state "cultivates" approval. Tyler (2006, p. 4) pointed out that this involves "a focus on people's internalized 
norms of justice and obligation [and] suggests the need to explore what citizens think and to understand their values". States theoretically appeal to citizens' senses of reciprocity, fairness and justice to gain normative compliance. Tyler (2006) argued that this is accomplished by increasing the transparency, consistency and equality of criminal justice processes, i.e. procedural justice. Procedural justice concerns individuals' "views about the appropriateness of the manner in which the [powerholders] exercise their authority" (Tyler, 2004, p. 91). A number of studies have shown that citizens who consider the treatment and decision-making processes of the police to be fair and informed are more likely to co-operate with the police (Tyler and Huo, 2002), trust criminal justice agents (Rottman, 2007; Tyler and Fagan, 2008) and obey the law (McClusky, 2003; Paternoster, Brame, Bachman and Sherman, 1997; Pruitt, Peirce, McGillicuddy, Welton and Castrianno, 1993).

Beyond procedural justice, Tankebe (2013) argued that there are multiple dimensions and paths to legitimation, including effectiveness, distributive justice and lawfulness. In democratic societies, state institutions are expected to provide certain "public goods" such as security, education and welfare, and there is a "normative expectation" that these goods are distributed fairly and that they produce the desired result (Tankebe, 2013, p. 10). Beetham (1991, p. 137) makes the point that legitimacy "requires both a morally authoritative source for government, and an ability to satisfy the ends which justify its enormous concentration of power." He argues that the most basic "ends" that the state is required to fulfil are the provision of security and social welfare. A state that is unable to provide these material needs (among others), or one that provides for only the preferred population, is at risk of being seen as illegitimate and losing citizens' compliance.

\section{The Cross-National Theoretical Framework}

The above reviewed definitions, theories and mechanisms of legitimacy provided context for considering the relationship between the state and its citizens and how this might affect social order: The state is the regulator of order through education, law and economy, and society must legitimate these means of control. Current cross-national theories tend to minimise the state in favour of economic risk factors 
(Nivette, 2011), but nevertheless provide an important framework in which to build a theory of the state, legitimacy and crime.

\section{"Grand Theories" of Crime}

There are three so-called "grand theories" used to explain cross-national variations in crime: modernisation theory, civilisation theory and conflict theory (Stamatel, 2009a, p. 14). Modernisation theorists argue that crime increases as states industrialise, weakening the collective conscience and control (see Clinard and Abbott, 1973; Shelley, 1981). Modernisation theory assumes that all states follow this 19th Century pattern of social change and institutional breakdown, resulting in weakened social control (Neapolitan, 1997). Civilisation theory, based primarily on the work of Elias (1939/2000), proposes that with social change comes personality change, whereby external behavioural controls shift to internalised self-controls. States that are more "civilised" - i.e. those that have successfully monopolised the use of force, provide formal conflict resolution and rely on economic demonstrations of success as opposed to physical (Elias, 1939/2000; Gurr, 1981) - have lower levels of crime. Again, this relies on the assumption of a common trajectory of state and social development. Finally, conflict theorists (or world systems theorists) propose that variations in crime across states are due to "uneven economic development within and across nations leading to inequality [and] exploitation..." (Stamatel, 2009a, p. 14). Neapolitan (1997, p. 75) explained that these perspectives rely on the argument that dominance by economic institutions causes "social miseries", "spiritual malaise" and "values of selfishness" leading to crime.

Although these theories were designed to explain cross-national variations in crime and violence, with the exception of civilisation theory, they tend to ignore the specialised role of the state in maintaining monopolies, regulating institutions and cultivating legitimacy. For instance, modernisation theorists often situate industrialisation and the transformation of the division of labour as the driving force behind changes in the social structure leading to anomie (Shelley, 1981). While industrialisation certainly affected the basic social constitution of modern societies, this does not necessarily lead to crime. Chamlin and Cochran (2005) argued that social destabilisation does not invite anomie unless it is accompanied by 
delegitimisation. Further, evidence that modernisation indicators alone cause crime is mixed at best (see Nivette, 2011; LaFree and Tseloni, 2006; Neapolitan, 1997; Stamatel, 2009a).

Only civilisation theory (Elias, 1939/2000) recognises the transformative role of the state in pacifying society. As described above, Elias argued that the monopolisation of force, driven by the need to extricate violence from economic exchange, changed the primary method of social control from external to internal. The state did so by replacing the need to enact private justice and worry about selfprotection with systems of formal and informal conflict resolution. Effective pacification requires a great deal of legitimacy in that citizens must willingly give up their known (and sometimes rather effective) tools of contract enforcement - i.e. threat and violence - to trust in the state's ability to secure justice and enforce the law. Unfortunately, civilisation theory is somewhat neglected in cross-national empirical research despite its historical support (Eisner, 2003; Spierenburg, 2008; cf. LaFree and Tseloni, 2006).

\section{Institutional Anomie and Crime}

Messner and Rosenfeld (2007) argued that institutional imbalances created by structural and cultural market dominance and weakening non-economic institutions (e.g. the family) lead to institutional breakdown and crime in what has been called "institutional anomie theory". Their theory rests on the idea of the "American Dream", which posits that Americans are particularly affected by this institutional imbalance due to the cultural emphasis on achieving monetary success. They claimed that their emphasis is not necessarily on the harmful conditions created by a dominant economic institution, but the effect this has on other institutions that provide social control (Messner and Rosenfeld, 2009). As shown in Nivette (2011), IAT gains moderate support in cross-national research.

Chamlin and Cochran (2007) argued that institutional anomie theory is not clear about how economic institutions come to dominate others, which values are particularly criminogenic and how social institutions respond to market infiltration. Although this places the validity of IAT in question, particularly in relation to other 
countries, the idea that "market values" can be harmful to social institutions and bonds is not without merit in criminological research (Karstedt and Farrall, 2006).

However, what IAT tends to overlook is that implicit in these perspectives is the role of the state in both fostering and protecting from the economic market and cultural goals (see Habermas, 1976). In ideal terms, the state is expected to foster economic growth and simultaneously protect its citizens from capitalism's harmful consequences (i.e. through social support, see Chamlin and Cochran, 1997; Halpern, 2001; Pratt and Godsey, 2002).

Institutional anomie theory is beneficial over "grand theories" in that it recognises the role of different institutions within society in creating and socialising rules and obedience to authority. Although it is somewhat vague about how these institutions interact, and which values "damage" and which values "strengthen" institutions and control, the theory at least brings us a step closer to understanding the connection between the state and citizens' behaviours.

\section{Democracy and Crime}

As shown above, much of the focus is on economic, family, education and welfare institutions, with little attention paid to political institutions (Karstedt, 2010; Stamatel, 2009a). The small but growing area of research on political institutions tends to concentrate on the effects of democracy and political transitions (e.g. Karstedt, 2003, 2006; LaFree and Tseloni, 2006; Lin, 2007; Stamatel, 2009b; Sung, 2004). Schwarzmantel (2010) argued that democracies are particularly concerned with levels of crime because conflict and group antagonism undermine the democratic principles of consensus and citizenship. Thus the values, practices and structures of democracies are ideally formed to exclude violence from both political and social realms. This conceptualisation is often only an ideal, and in reality democracies face the constant challenge of balancing principles of individualism and inclusion with tensions brought by weak ties and self-expression (Karstedt, 2006). In these ideally inclusive states, inequalities may "have a particularly detrimental impact", and "[i]f democracies do not 'make good' on their promises, it might elicit violent reactions among those who feel themselves to be victims of discrimination" (Karstedt, 2006, p. 60). 
It is important to note that while democracies contain these inherent tensions, and certainly the possibility of extreme violence, most fully democratic states have very low levels of homicide (e.g. Western Europe, Scandinavia, Canada, Japan, see WHO, 2013). Karstedt (2006) reported that violence was lowest where states promoted democratic values upheld by egalitarian structures. In states where values of tolerance and inclusion are coupled with discrimination, inequality and repression, violence is comparatively higher. For instance, where the state is perceived to treat certain groups unfairly, citizens may see this as a violation of the promised democratic principles of equality and justice. Thus the state is no longer justified according to shared beliefs, and citizens may withdraw consent, and ultimately compliance.

\section{Legitimacy and Crime}

If legitimacy is a key component to understanding levels of social order, we must consider how illegitimacy leads to crime and violence. Cross-national theory provides several contexts in which the criminogenic nature of illegitimacy is apparent: when there is disjunction between state actions and values and during social and political transformations/breakdowns. The first has implications for certain groups and individuals who experience unfairness, injustice and inequality at the hands of the state. To borrow Habermas' (1976) phrase, these citizens reside in the "legitimation gap". The second has universal implications in that states and institutions are constantly changing, requiring constant cultivation of legitimacy in order to maintain normative compliance as institutions weaken. The following sections will discuss these pathways from illegitimacy to crime more thoroughly. It is important to note that these legitimation mechanisms reflect an ongoing "dialogue" between the state and its citizens (Bottoms and Tankebe, 2012), and so each pathway should allow for feedback effects.

\section{Lack of Legitimacy and Social Control}

The first possibility is that a lack of legitimacy discourages citizens from using the criminal justice system to solve interpersonal conflicts. This argument is based on 
the ability of the state to hold the monopoly of force, solve conflicts and to provide justice in return (Elias, 1939/2000; Hobbes, 1651/1996; Weber, 1978). Where the police are perceived as illegitimate agents of social control, citizens may fill this gap using their own tools of conflict resolution, including violence (Black, 1983).

Researchers argue that police are often considered a visible representation of the state's monopoly of violence and moral identity (Tankebe, 2013). As such, conceptions of illegitimacy are likely to stem from interactions between criminal justice agents and citizens. Conceptions of illegitimacy would therefore include illegal actions and unfair treatment by criminal justice power-holders, inequality of outcomes within the criminal justice system, and conflicting moral values and identities between power-holders and citizens. Any of these examples supposedly reflects a lack of legitimacy in the moral authority of the state, as represented by its criminal justice institutions. Previous studies support the premise that legal actors, amongst others, can shape individual perceptions of legitimacy, and that these perceptions change as more information and experiences are processed (Fagan and Piquero, 2007; Fagan and Tyler, 2005; Kirk and Papachristos, 2011; Sunshine and Tyler, 2003).

The primary mechanism at work here is the delegitimisation of the state's criminal justice system, which weakens the monopoly of violence, causing individuals to use violence as a tool to mete out justice and resolve conflicts. This process is illustrated in Figure 1 using Coleman's (1986) macro-micro-macro causal social mechanisms. Indicated by the first arrow (1), unjust, discriminatory and illegal actions perpetrated by the state, and especially the police, lead citizens to perceive the criminal justice system as illegitimate. Delegitimisation causes citizens to reject the state's monopoly of physical force and turn to self-help (2), the effects of which contribute to higher levels of crime and violence (3).

[Figure 1 about here]

Although this mechanism has yet to be tested, certain individual pathways are well supported in criminology. We know based on Tyler's (2004, 2006; Hagan et al., 2005; Reisig and Lloyd, 2009; Sunshine and Tyler, 2003; Tankebe, 2013) work that 
distributive injustice, procedural injustice and ineffectiveness lead citizens to withdraw support and cooperation from the criminal justice system (arrow 1). Upon interviewing a sample of young men (ages 16-24) recently involved in violent offences, Wilkinson, Beaty and Lurry (2009, p. 29) found that the youth experienced a "profound lack of access to the law" (arrow 1). The participants in their study continually expressed a lack of confidence in the police that drove them to keep guns for protection and use violence to solve conflict (arrow 2). In a study of retaliatory homicides in St. Louis, Missouri, Kurbin and Weitzer (2003) found that violent self-help is part of the "code of the streets" (Anderson, 1999), and that this "code" functions where police are seen as illegitimate (arrow 2).

As suggested by the diverse examples above, self-help can manifest in a number of ways. Where criminal justice actors and institutions are seen as unjust, unfair and ineffective, a vacuum of power may exist, allowing for opposing value systems, illegal markets, and alternative (sometimes violent) forms of social control to move in and fulfill the need for order.

The literature on vigilantism provides a number of situations where ineffectiveness and injustice delegitimize the criminal justice system, leading to an unavailability of law, and consequently self-help. For example, Goldstein (2003, p. 36) interviewed a number of community members and leaders in the barrios of Cochabamba, Bolivia, finding that vigilante violence is a direct challenge to state legitimacy, in that it "accus[es] the legal authorities of neglecting the needs of the people, deploying the inclusive discourse of citizenship to forge a new kind of political relationship between the marginal communities and the state." In the words of one resident, "If you as the authority do not make justice, then we are going to make it with our hands" (quoted in Goldstein, 2003, p. 30).

Similarly, Varese (2011) argues that state ineffectiveness and illegitimacy are key 'local conditions' for the migration and growth of organized crime groups. When a state cannot protect its citizens, settle disputes, or enforce economic contracts, a demand arises for extra-legal protection typically provided by mafias. Organized crime groups, in addition to perpetrating acts of violence themselves, arguably foster "social and moral networks" within controlled areas that value violence as retaliation (Loftin, 1986). For instance, in Jamaica, Reisig and Lloyd (2009) found that the 
presence of area "dons" inhibited students' cooperation with the police. Crossnationally, Van Dijk (2007) found that effective and 'incorruptable' criminal justice systems are negatively associated with the presence of organized crime groups.

The analytical strategy needed to test these hypothetical relationships should be adaptable to different locations and contexts, but still test the core premise. Simplistically, this requires measuring levels of criminal justice legitimacy, individual perceptions of the state's right to hold the monopoly of force, and individual criminal behaviours. Ideally, analyses should measure changes in legitimacy, attitudes, and behaviours over time in order to detect whether the proposed links are in fact causal.

In addition, the above review has highlighted a number of potential moderators and confounding variables that should be accounted for in future analyses. In relation to both cooperation with the police, vigilantism and organized crime, community levels of cohesion and trust may moderate the effect of legitimacy on crime. Sunshine and Tyler (2003) reported that moral cohesion within the community enhanced the legitimacy and hence cooperation with the police. Conversely, Zizumbo-Colunga (2010) found that high levels of cohesion - measured by trust - can be a barrier to cooperation, leading to more support for vigilantism. This suggests that the relationship between legitimacy and violence may not be linear: in societies with low levels of legitimacy, building too much cohesion and trust may have the opposite effect, creating the "wrong kind" of social capital.

Another potential moderator is the existence of social supports, or "safety nets" (Colvin, Cullen, and Vander Ven, 2002). Colvin et al. (2002) argue that support differentially affects individuals and communities, depending on how consistently it is administered (i.e. consistent versus erratic support) and from whom it is offered (i.e. legal versus illegal support). Consistent and legal types of social support - such as neighbourhood cohesion, religious organisations and social welfare - may minimise the effect of illegitimacy on violence. The more "safety nets" available to citizens, the less likely they are to revoke the state's monopoly and use violent selfhelp. Social support and cohesion may be key to understanding why certain individuals subject to illegitimate state institutions, including a lack of security, unfairness, and abuses turn to other forms of political participation to affect change. 


\section{Legitimacy, institutional commitment, and informal social control}

The second pathway focuses on the role of institutions - economic, political, family, welfare, education, criminal justice - in maintaining order by embedding individuals in obligations, instilling non-violent moralities, constructing social interactions based on trust and reciprocity, and overall encouraging obedience to authority and a willingness to cooperate as agents of informal social control (LaFree, 1998; Hearn, 1997; Karstedt, 2010). LaFree (1998; see also Granovetter, 1985; Hearn, 1997; Roth, 2009) argued that since humans are embedded in these obligations, when institutions begin to "lose legitimacy", people feel less obligated to abide by their responsibility to participate in social control and comply with formal and informal rules. Essentially, an institutional loss of legitimacy leads to crime because citizens withdraw compliance to the rules, but more importantly they withdraw commitment to policing the state's monopoly.

As with the first pathway, unjust and discriminatory criminal justice institutions may delegitimize the authority of the state and the rule of law amongst citizens. However, police and courts are not the only source of legitimation in society, and "legal socialization" (Fagan and Tyler, 2005) occurs through the development of relationships, rules, and obligations across a number of institutions. This includes political, family, economic, education, welfare, religion, military, and employment institutions, among others.

In political institutions, a tyrannical dictator, unfair or exclusive electoral system, or an unrepresentative national parliament may all be sources of illegitimacy to citizens. Within economic and work institutions, unequal pay, non-meritocratic promotions, and poor or dangerous working conditions may delegitimize and weaken commitment to these institutions. In family institutions, power structures vary across societies, but generally authority lies with the parents. Family authority may weaken if parents are cruel, violent, or if parental values differ drastically from children's (e.g. as in immigrant households and first generation children). In addition, family institutions play a role in forming beliefs and attitudes towards the law and police, meaning illegitimate family institutions may fail to instill certain legitimizing 
legal attitudes. Education and welfare institutions may lose legitimacy by discriminating against certain groups, providing unequal services, or as further extensions of state power, they may suffer tangentially from political illegitimacies. Religious institutions contain a variety of rules, authority structures, and laws (both natural and legal), and thus play a unique role in the legitimization and delegitimisation of the state amongst committed citizens.

The mechanisms linking legitimacy to crime here occur in two parts. Generally speaking, each institution provides sets of rules that promote or discourage certain behaviors, and optimally there exists an equilibrium in which legitimate institutions work to embed individuals in networks and patterns that result in a diffuse obligation to obey authority (March and Olsen, 2006; Messner and Rosenfeld, 2007). The delegitimisation of institutions causes disruptions to this potential (and likely unobtainable) equilibrium, weakening obligations, and loosening normative control over citizens. The second mechanism is the breakdown of social control caused by the withdrawal of commitment and weakening of obligations to the rules and patterns of institutions. This affects levels of crime in two main ways: by loosening social bonds and discouraging citizens from participating in informal social control (LaFree, 1998; Nivette and Eisner, 2013).

To be clear, Figure 2 illustrates this relationship in terms of causal social mechanisms (Coleman, 1986). The process occurs in two stages. First, indicated by arrow (1), injustice, discrimination and corruption lead citizens to perceive the state as illegitimate. Delegitimisation causes citizens to withdraw commitment to social institutions (2), the effects of which destabilize and break down social institutions (3). In the second stage, institutional breakdown weakens obligations and social controls (4). As a result, social bonds are loosened, participation in informal social control is discouraged, and individuals commit more opportunistic and moralistic crime (5), which contributes to overall levels of crime and violence (6).

[Figure 2 about here]

Again, individual links have been empirically examined. It is also well established that disruptions to social institutions (arrow 4) disorganize and reduce 
individuals' willingness to participate in informal social control (i.e. through losses of cohesion and collective efficacy, see Sampson, Raudenbush, and Earls, 1997). Further, the loss of informal social controls (arrow 5) has been shown to predict individual delinquency (Sampson and Laub, 2008). Indeed, Sampson and Laub (2008) provide compelling longitudinal evidence that commitment to certain institutions such as marriage, employment, and religion can significantly alter an individual's criminal career.

The content and context in which institutional rules, beliefs, and behaviours exist is essential to unpacking how these complex, interdependent institutions control and/or cause crime and violence. One theoretical framework that may assist this endeavor is institutional anomie theory (Messner and Rosenfeld, 2007), which focuses on the balance of power between institutions and the subsequent effect on values and social control. Rosenfeld (2004) elaborates briefly on the consequences of non-economic domination, but this avenue requires more theoretical and empirical development in order to understand the delegitimizing effects of various balances of power in society.

Measuring and testing the institutional pathway requires us to first understand the institutional layout of a society. It is likely that institutional balances, as well as norms, rules, and patterns associated with each institution, vary across the globe. However, we may be able to group certain societies for comparison by political, economic, or social organization (e.g. advanced welfare states or newly industrialized countries). By doing so, we would expect institutions in these societies to be relatively similar in structure, power distribution, and value content, and so would hypothetically respond to delegitimisation in a comparable fashion. For instance, Pratt (2008) argues that the phenomenon of low-imprisonment in Scandinavian societies is related to shared institutional characteristics, including bureaucratic autonomy from political influence and strong welfare traditions.

Yet another layer of dialogue to add to this model is between state and subnational state actors (i.e. police departments, district courts, school districts). The focus so far has largely centred on state agents and agencies as aggregate nationallevel institutions, but this misses a range of diversity across neighbourhoods, cities and counties. The extent to which these meso-level organisations engage in the 
dialogue is likely dependent on the extent of institutional interdependency and centralisation (or conversely, agencies may be "insulated" from other institutions, Karstedt, 2010). The resulting multilevel model is rather complex, but it is nevertheless important to structure these conversations of legitimacy in order to grasp how reactions at various levels impact social order.

Second, we must understand who are the power-holders within each institution in order to appropriately measure levels of legitimacy, commitment, and obligation. In criminal justice institutions, researchers typically use police as representative power-holders, but can we make the same assumption about teachers, parents, managers, imams, and social workers? Or should we instead focus on evaluating the legitimacy of the processes of educational attainment, parenting, hiring and firing, religious education, and the provision of social support, respectively? It is likely that legitimacy is evaluated based on both power-holder actions and institutional processes.

Third, in order to test the link between delegitimisation and institutional withdrawal, a measure of commitment and obligation is needed. This brings up a number of important questions about the causal process of commitment to, participation in and abandonment of institutions. For instance, an important confounding factor to consider in this context is "dull compulsion," or a ritualistic adherence to prescribed roles (Bottoms and Tankebe, 2012; Carrabine, 2004). Citizens that "dully comply" feel little moral obligation to participate beyond the routine fulfillment of institutional roles. In other words, they comply with the rules, but feel no obligation to enforce them (i.e. participate in informal social control). This may also be the case in situations where citizens comply due to "sheer fear" or "material inducement" (Carrabine, 2004, p. 184): compliance is secured, but active commitment is absent.

These distinctions portray more nuanced pathways connecting institutional legitimacy to crime. Illegitimate polities and institutions induce the withdrawal of moral commitment to the non-violent rules of social interaction, but they may also lead to routine obedience (Johnson et al., 2006). Researchers must investigate citizens' motivations for non-normative compliance and its effect on social order (Bottoms and Tankebe, 2012). 


\section{Summary: A Multilevel Model of Legitimacy and Crime}

These perspectives are not mutually exclusive, and most likely work together to disrupt participation in institutions and social controls, reject the state's monopoly and morally validate the use of violence for self-help. Changes brought by modernisation, imbalances between economic and social institutions, inequalities and democratisation all undoubtedly alter the foundations of social life, but these factors are - to use Wikström's (2006, p. 62) phrase - "causes of the causes". What leads citizens to break from normative compliance and ignore obligations to violate moral rules and laws may be the delegitimisation of authority. Legitimacy offers a direct link between the institutions that hold authority and demand obedience (in particular political institutions) and individual rule-breaking, crime and violence.

However, more research must be done on how these mechanisms operate on an individual psychological and situational level. Wikström's (2006) situational action theory is particularly relevant here because it provides a framework for multilevel integration of theory and analysis. Specifically, situational action theory proposes that socio-structural characteristics (e.g. concentrated disadvantage, political capital, policing policy and effectiveness) interact with individual characteristics (e.g. legal attitudes, self-control, morality) to influence choices in a given situation (Wikström, Oberwittler, Treiber and Hardie, 2012). For instance, attitudes related to the legitimacy of authority are likely to directly impact an individual's perceptions of crime alternatives in criminogenic settings. An example of a criminogenic setting is a neighbourhood characterised by concentrated disadvantage, aggressive policing tactics and low social capital (Kane, 2005; Kirk and Papachristos, 2011; Sampson and Bartusch, 1998). In situations that generate a choice between breaking rules and not breaking rules, feelings that the police are unjust, corrupt or ineffective may lead an individual to choose the criminal option.

Together this theoretical model illustrates the dialogical nature of legitimacy and thus the cyclical connection between state actions and citizens' behaviours. Illegitimate institutions - characterised by violence, discrimination, inequality and unfairness - lead to crime through the revocation of the monopoly on violence and/or the deterioration of informal social controls. In this model, violence may be 
considered a reaction to state illegitimacy. Crime and violence may therefore be interpreted as moral declarations that the state does not hold the monopoly on force and that it does not properly care for its citizens. The state may either react positively by changing policy to influence institutions, altering its values to coincide with citizens' or providing further "safety nets" (Colvin et al., 2002) to prevent institutional breakdowns. The state may also react negatively by either using physical coercion to gain compliance or doing nothing.

With positive reactions, states are working to improve legitimacy by increasing institutional fairness, transparency and justice. These reactions demonstrate the state is using power in a way that is acceptable amongst the populace and that its authority is justifiable. Consequently citizens comply with state monopoly and institutional rules, and crime decreases. Negative reactions such as police crackdowns, excessive use of force and (an extreme) ethnic cleansing may further inequalities, unfairness and discrimination and increase crime and violence. Since crackdowns are likely to target citizens in the "legitimation gap", problems of mistrust and illegitimacy only intensify the preference for self-help. Furthermore, constant pressure for change from global social forces such as modernisation and democratisation means that inaction will only increase institutional breakdown and illegitimacy.

\section{Conclusion}

This paper sought to fill a significant gap in cross-national criminological theory, namely the lack of consideration given to the role of the state in building and maintaining social order. The state is linked to levels of social order via political interrelations with other social institutions and the claim on the monopoly on legitimate force. The state's monopolisation of force must be accepted across large geographical areas and diverse populations, and the most effective method of accomplishing widespread compliance may be through legitimacy. Legitimacy is gained when political, social and economic institutions are fair, transparent, justified according to shared beliefs and when they provide basic social goods such as security and social welfare. Most importantly, an illegitimate state may cause crime 
and violence when citizens withdraw commitment from institutions (LaFree, 1998) and/or reject the monopoly of physical force to employ self-help (Black, 1983). 


\section{Notes}

1 Wrong $(2004$, p. 35) defines authority as "successful ordering or forbidding".

2 While this is potentially an important route, for brevity and relevance this paper will focus on the second route (i.e. legitimation). 


\section{References}

Acemoglu, Daron, Johnson, Simon and James A. Robinson (2005) 'Institutions as a Fundamental Cause of Long-Run Growth', in Philippe Aghion and Steven N. Durlauf (eds), Handbook of Economic Growth, Volume 1A, pp. 385-472. London: Elsevier.

Anderson, Elijah (1999) Code of the Street: Decency, Violence, and the Moral Life of the Inner City. New York: W.W. Norton and Company.

Apel, Robert and Daniel S. Nagin (2011) 'General Deterrence: A Review of Recent Evidence', in James Q. Wilson and Joan Petersilia (eds), Crime and Public Policy, pp. 411-436. Oxford: Oxford University Press.

Bates, Robert H., Block, Steven A., Fayad, Ghada and Anke Hoeffler (2012) 'The New Institutionalism and Africa', Journal of African Economies, doi: 10.1093/jae/ejs031.

Beetham, David (1991) The Legitimation of Power. London: MacMillan.

Bingham, Tom (2010) The Rule of Law. London: Allen Lane.

Black, Donald (1983) 'Crime as Social Control', American Sociological Review, 48(1), 34-45.

Bottoms, Anthony E. (2002) Morality, Crime, Compliance and Public Policy, in Anthony E. Bottoms and Michael Tonry (eds), Ideology, Crime and Criminal Justice: A Symposium in Honour of Sir Leon Radzinowicz, pp. 20-54. Cullompton: Willan Publishing.

Bottoms, Anthony E. and Justice Tankebe (2012) 'Beyond Procedural Justice: A Dialogic Approach to Legitimacy in Criminal Justice', The Journal of Criminal Law and Criminology, 102(1), 119-170.

Carrabine, Eamonn (2004) Power, Discourse and Resistance: A Genealogy of the Strangeways Prison Riot. Aldershot: Ashgate.

Chamlin, Mitchell B. and John K. Cochran (2007) 'An Evaluation of the Assumptions that Underlie Institutional Anomie Theory', Theoretical Criminology, 11(1), 3961. 
Chamlin, Mitchell B. and John K. Cochran (2005) 'Ascribed Economic Inequality and Homicide Among Modern Societies: Toward the Development of a CrossNational Theory', Homicide Studies, 9(1), 3-29.

Chamlin, Mitchell B. and John K. Cochran (1997) 'Social Altruism and Crime', Criminology, 35(2), 203-228.

Clinard, Marshall B. and Daniel J. Abbott (1973) Crime in Developing Countries: A Comparative Perspective. New York: John Wiley and Sons.

Coicaud, Jean-Marc (2007) Legitimacy and Politics: A Contribution to the Study of Political Right and Political Responsibility. Cambridge: Cambridge University Press.

Coleman, James S. (1986) Foundations of Social Theory. Cambridge, MA: Harvard University Press.

Colvin, Mark, Cullen, Francis T. and Thomas Vander Ven (2002) 'Coercion, Social Support, and Crime: An Emerging Theoretical Consensus', Criminology, 40(1), 19-42.

Cooney, Mark (1997) 'The Decline of Elite Homicide', Criminology, 35(3), 381-407.

Eisner, Manuel (2003) 'Long-Term Historical Trends in Violent Crime', Crime and Justice, 30, 83-142.

Elias, Norbert (1939/2000) The Civilizing Process. Oxford: Blackwell.

Fagan, Jeffrey and Alex R. Piquero (2007) 'Rational Choice and Developmental Influences on Recidivism Among Adolescent Felony Offenders', Journal of Empirical Legal Studies, 4(4), 715-748.

Fagan, Jeffrey and Tom R. Tyler (2005) 'Legal Socialization of Children and Adolescents', Social Justice Research, 18(3), 217-242.

Fund for Peace (2013) The Failed States Index 2013. Retrieved 24 June 2013, from http://ffp.statesindex.org/rankings-2013-sortable.

Gilley, Bruce (2009) The Right to Rule: How States Win and Lose Legitimacy. New York: Columbia University Press.

Goldstein, Daniel M. (2003) "In our own hands": Lynching, Justice, and the Law in Bolivia', American Ethnologist, 30(1), 22-43.

Granovetter, Mark (1985) 'Economic Action and Social Structure: The Problem of Embeddedness', American Journal of Sociology, 91(3), 481-510. 
Gurr, Ted R. (1981) 'Historical Trends in Violent Crime: A Review of the Evidence', Crime and Justice: A Review of Research, 3, 295-350.

Habermas, Jürgen (1976) Communication and the Evolution of Society. Cambridge, UK: Polity Press.

Hagan, John, Shedd, Carla, and Monique R. Payne (2005) 'Race, Ethnicity, and Youth Perceptions of Criminal Injustice', American Sociological Review, 70(June), 381-407.

Halpern, David (2001) 'Moral Values, Social Trust and Inequality: Can Values Explain Crime?' British Journal of Criminology, 41(2), 236-251.

Hearn, Frank (1997) Moral Order and Social Disorder: The American Search for Civil Society. New York: Aldine de Gruyter.

Hobbes, Thomas (1651/1996) Leviathan. Oxford: Oxford University Press.

Hough, Mike, Jackson, Jonathan, Bradford, Ben, Myhill, Andy and Paul Quinton (2010) 'Procedural Justice, Trust, and Institutional Legitimacy', Policing, 4(3), 203-210.

Johnson, Cathryn, Dowd, Timothy J. and Cecilia L. Ridgeway (2006) 'Legitimacy as a Social Process', Annual Review of Sociology, 32, 52-78.

Kane, Robert J. (2005) 'Compromised Police Legitimacy as a Predictor of Violent Crime in Structurally Disadvantaged Communities', Criminology, 43(2), 469498.

Karstedt, Susanne (2003) 'Legacies of a Culture of Inequality: The Janus Face of Crime in Post-Communist Countries', Crime, Law and Social Change, 40, 295-320.

Karstedt, Susanne (2006) 'Democracy, Values, and Violence: Paradoxes, Tensions, and Comparative Advantages of Liberal Inclusion', The Annals of the American Academy of Political and Social Science, 605(1), 50-81.

Karstedt, Susanne (2010) 'New Institutionalism in Criminology: Approaches, Theories and Themes', in Eugene McLaughlin and Tim Newburn (eds), The Sage Handbook of Criminological Theory, pp. 337-359. London: Sage.

Karstedt, Susanne and Stephen Farrall (2006) 'The Moral Economy of Everyday Crime: Markets, Consumers and Citizens', British Journal of Criminology, 46(6), 1011-1036. 
Kirk, David S. and Andrew V. Papachristos (2011) 'Cultural Mechanisms and the Persistence of Neighborhood Violence', American Journal of Sociology, 116(4), 1190-1233.

Kurbin, Charis E. and Ronald Weitzer (2003) 'Retaliatory Homicide: Concentrated Disadvantage and Neighborhood Culture', Social Problems, 50(2), 157-180.

LaFree, Gary (1998) Losing Legitimacy: Street Crime and the Decline of Social Institutions in America. Oxford: Westview Press.

LaFree, Gary (2005) 'Evidence for Elite Convergence in Cross-National Homicide Victimization Trends, 1956 to 2000', The Sociological Quarterly, 46(1), 191211.

LaFree, G. and A. Tseloni (2006) 'Democracy and Crime: A Multilevel Analysis of Homicide Trends in Forty-Four Countries, 1950-2000', The Annals of the American Academy of Political and Social Science, 605(1), 25-49.

Lin, Ming-Jen (2007) 'Does Democracy Increase Crime? The Evidence from International Data', Journal of Comparative Economics, 35(3), 467-483.

Loftin, C. (1986) 'Assaultive Violence as a Contagious Social Process', Bulletin of New York Academy of Medicine, 62(5), 550-555.

Mann, Michael (1986) The Sources of Social Power, Volume 1: A History of Power from the Beginning to A.D. 1760. Cambridge: Cambridge University Press.

March, James G. and Johan P. Olsen (2006) 'Elaborating the "New Institutionalism"', in R.A.W. Rhodes, Sarah A. Binder and Bert A. Rockman (eds), The Oxford Handbook of Political Institutions, pp. 3-20. Oxford: Oxford University Press.

McCluskey, John D. (2003) Police Requests for Compliance: Coercive and Procedurally Just Tactics. New York: LFB Scholarly Publishing.

MacCoun, Robert J. (1993) 'Drugs and the Law: A Psychological Analysis of Drug Prohibition', Psychological Bulletin, 113(3), 497-512.

Messner, Steven F. and Richard Rosenfeld (2007) Crime and the American Dream. Belmont, CA: Thomas Wadsworth.

Messner, Steven F. and Richard Rosenfeld (2009) 'Institutional Anomie Theory: A Macro-Sociological Explanation of Crime', in Marvin D. Krohn, Alan J. Lizotte, and Gina Penly Hall (eds), Handbook on Crime and Deviance, pp. 209-224. London: Springer. 
Neapolitan, Jerome L. (1997) Cross-National Crime: A Research Review and Sourcebook. Westport, CT: Greenwood Publishing Group.

Nivette, Amy E. (2011) 'Cross-National Predictors of Crime: A Meta-Analysis', Homicide Studies, 15(2), 103-131.

Nivette, Amy E. and Manuel Eisner (2013) 'Do Legitimate Polities have Fewer Homicides? A Cross-National Analysis', Homicide Studies, 17(1), 3-26.

Paine, Thomas (1776) Common Sense. London: Penguin Books.

Paternoster, Raymond, Brame, Robert, Bachman, Ronet and Lawrence Sherman (1997) 'Do Fair Procedures Matter? The Effect of Procedural Justice on Spouse Assault', Law and Society Review, 31(1), 173-217.

Pratt, John (2008) 'Scandinavian Exceptionalism in an Era of Penal Excess: Part I: The Nature and Roots of Scandinavian Exceptionalism', British Journal of Criminology, 48(2), 119-137.

Pratt, Travis C. and Timothy W. Godsey (2002) 'Social Support and Homicide: A Cross-National Test of an Emerging Criminological Theory', Journal of Criminal Justice, 30(6), 589-601.

Pruitt, Dean C., Peirce, Robert S., McGillicuddy, Neil B., Welton, Gary L. and Lynn M. Castrianno, (1993) 'Long-Term Success in Mediation', Law and Human Behavior, 17(3), 313-330.

Reisig, Michael D. and Camille Lloyd (2009) 'Procedural Justice, Police Legitimacy, and Helping the Police Fight Crime: Results from a Survey of Jamaican Adolescents', Police Quarterly, 12(1), 42-62.

Rosenfeld, Richard (2004) 'Terrorism and Criminology', in Mathieu Deflem (ed), Terrorism and Counter-Terrorism: Criminological Perspectives, pp. 19-32. London: Elsevier.

Roth, Randolph (2009) American Homicide. Cambridge: Harvard University Press.

Rottman, David B. (2007) 'Adhere to Procedural Fairness in the Justice System', Criminology and Public Policy, 6(4), 835-842.

Sampson, Robert J. and Dawn Jeglum Bartusch (1998) 'Legal Cynicism and (Subcultural?) Tolerance of Deviance: The Neighborhood Context of Racial Differences', Law \& Society Review, 32(4), 777-804. 
Sampson, Robert J. and John H. Laub (2008) 'A General Age-Graded Theory of Crime: Lessons Learned and the Future of Life-Course Theory', in David P. Farrington (ed), Integrated Developmental and Life-Course Theories of Offending, pp.165182. London: Transaction Publishers.

Sampson, Robert J., Raudenbush, Stephen W. and Felton Earls (1997) 'Neighborhoods and Violent Crime: A Multilevel Study of Collective Efficacy', Science, 277(5328), 918-924.

Schwarzmantel, John (2010) 'Democracy and Violence: A Theoretical Overview', Democratization, 17(2), 217-234.

Shelley, Louise I. (1981) Crime and Modernization: The Impact of Industrialization and Urbanization on Crime. Carbondale: Southern Illinois University Press.

Spierenburg, Pieter (2008) A History of Murder: Personal Violence in Europe from the Middle Ages to the Present. Cambridge: Polity.

Stamatel, Janet P. (2009a) 'Contributions of Cross-National Research to Criminology at the Beginning of the 21st Century', in Marvin D. Krohn, Alan J. Lizotte and Gina Penly Hall (eds), Handbook on Crime and Deviance, pp. 3-22. London: Springer.

Stamatel, Janet P. (2009b) 'Correlates of National-level Homicide Variation in PostCommunist East-Central Europe', Social Forces, 87(3), 1423-1488.

Sung, Hung-En (2006) 'Democracy and Criminal Justice in Cross-National Perspective: From Crime Control to Due Process', The Annals of the American Academy of Political and Social Science, 605(1), 311-337.

Sunshine, Jason and Tom Tyler (2003) 'Moral Solidarity, Identification with the Community, and the Importance of Procedural Justice: The Police as Prototypical Representatives of a Group's Moral Values', Social Psychological Quarterly, 66(2), 153-165.

Tankebe, Justice (2008) 'Colonialism, Legitimation, and Policing in Ghana', International Journal of Law, Crime and Justice, 36(1), 67-84.

Tankebe, Justice (2013) 'Viewing things Differently: The Dimensions of Public Perceptiosn of Police Legitimacy', Criminology, 51(1), 103-135.

Tyler, Tom R. (2004) 'Enhancing Police Legitimacy', The Annals of the American Academy of Political and Social Science, 593, 84-99. 
Tyler, Tom R. (2006) Why People Obey the Law. Princeton, NJ: Princeton University Press.

Tyler, Tom R. and Jeffrey Fagan (2008) 'Legitimacy and Cooperation: Why Do People Help the Police Fight Crime in Their Communities?' Ohio State Journal of Criminal Law, 23(1), 231-275.

Tyler, Tom R. and Y.J. Huo (2002) Trust in the Law: Encouraging Public Cooperation with the Police and Courts. New York: Russell Sage Foundation.

Van Dijk, Jan (2007) 'Mafia Markers: Assessing Organized Crime and its Impact Upon Societies', Trends in Organized Crime, 10(4), 39-56.

Varese, Federico (2011) 'Mafia Movements: A Framework for Understanding the Mobility of Mafia Groups', Global Crime, 12(3), 218-231.

Weber, Max (1978) Economy and Society, Vol. 1. Berkeley, CA: University of California Press.

Wikström, Per-Olof (2006) 'Individuals, Settings, and Acts of Crime: Situational Mechanisms and the Explanation of Crime', in Per-Olof Wikström and Robert J. Sampson (eds), The Explanation of Crime: Context, Mechanisms and Development, pp. 61-107. Cambridge: Cambridge University Press.

Wikstrom, Per-Olof H., Oberwittler, Dietrich, Treiber, Kyle, and Hardie, Beth (2012) Breaking rules: The Social and Situational Dynamics of Young People's Urban Crime. Oxford: Oxford University Press.

Wilkinson, Deanna L., Beaty, Chauncey C. and Regina M. Lurry (2009) 'Youth Violence - Crime or Self-Help? Marginalized Urban Males' Perspectives on the Limited Efficacy of the Criminal Justice System to Stop Urban Youth Violence', The Annals of the American Academy of Political and Social Science, 623, 25-38.

World Health Organisation (2013) 'Death and Injury Country Estimates: Death Estimates for 2008 by cause for WHO Member States', available at: http://www.who.int/healthinfo/global_burden_disease/estimates_country/e n/index.html [Accessed June 26, 2013].

Wrong, Dennis H. (2004) Power: Its Forms, Bases, and Uses. London: Transaction Publishers.

Zizumbo-Colunga, Daniel (2010) 'Explaining Support for Vigilante Justice in Mexico', AmericasBarometer Insights, 39, 1-12. 
Figure 1. Proposed Mechanisms Linking The State, Legitimacy, Self-Help and Crime

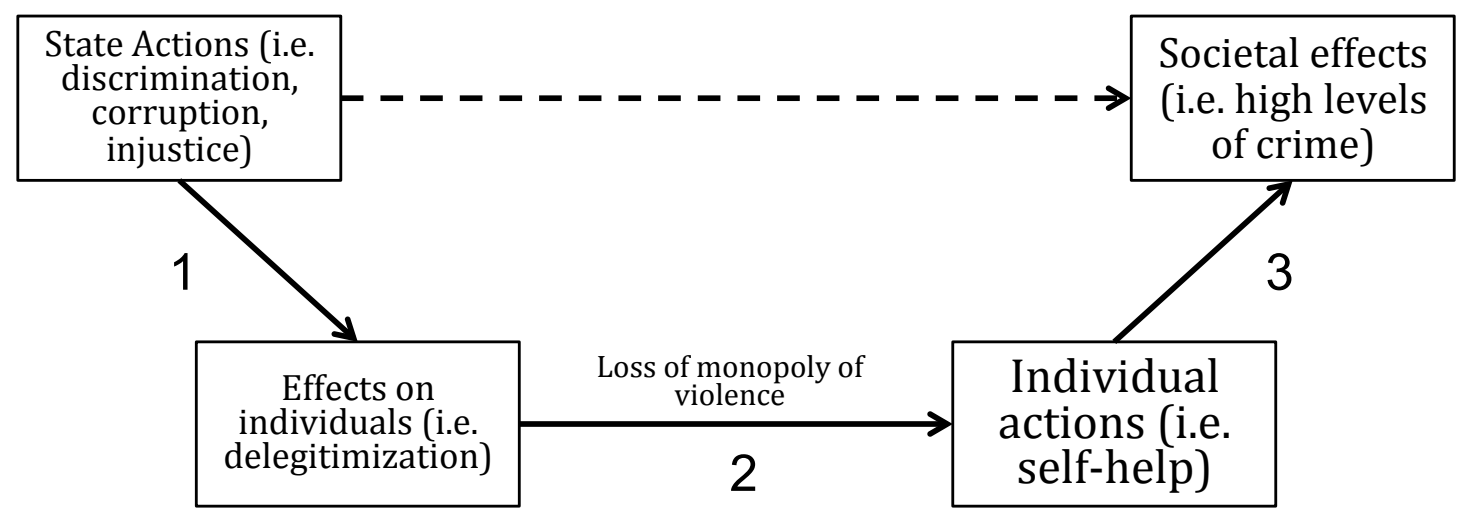


Figure 2. Proposed Mechanisms Linking The State, Legitimacy, Institutional Breakdown and Crime

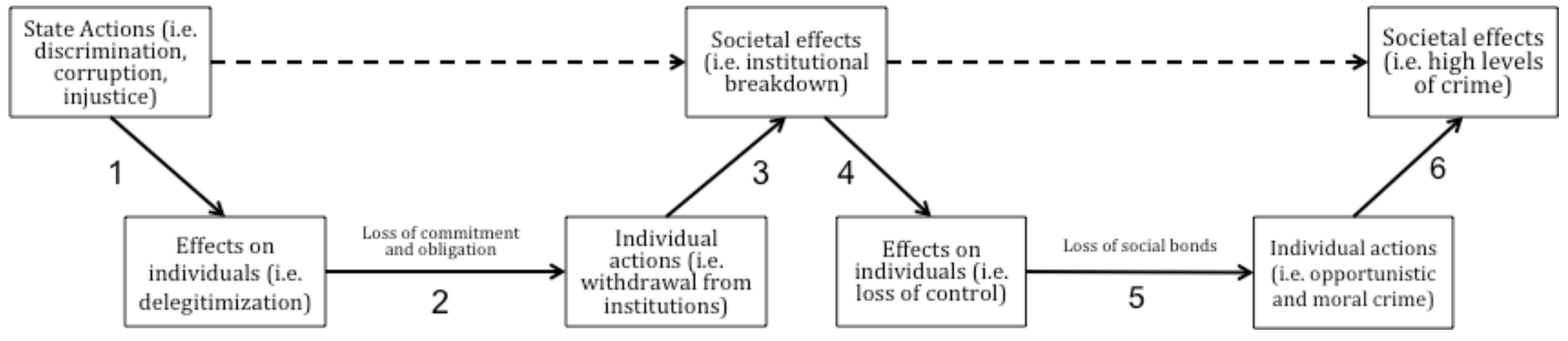

